\title{
Telekomünikasyon Sektöründe Müşteri Memnuniyeti ve Müşteri Değerinin Tavsiye Etme Niyetine Etkisi
}

\author{
Davut KARAMAN ${ }^{1}$
}

$\ddot{O} z$

Müşteri işletmelerin faaliyetlerini devam edebilmeleri için en önemli bir unsurdur. Iş̧letmeler sahip oldukları müşterileri elde tutmak isterken pazar paylarının artırarak potansiyel müşterileri de hizmet sağlamak istemektedir. Bu noktada en önemli reklam araçlarından biri olan mevcut müşterilerin tavsiye etme niyetleri işletmeler için önem kazanmaktadır. Çünkü mevcut müșterilerini memnun eden ve müșteri değeri yaratan ișletmeleri müșterileri arkadaşları, aileleri ve çevresine tavsiye etme eğilimine girebilmektedir. Bu bağlamda çalışmanın amacı müşteri memnuniyeti ve müşteri değerinin tavsiye etme niyetine etkisinin Türkiye'deki telekomünikasyon sektöründe demografik değişkenler bağlamında incelenmesidir. Alanya ilçesinde $Y$ ve Z kuşak katılımcılardan veri toplanmıştır. Öncelikle, regresyon modelinde kullanmak için ölçeklerin faktör analizi gerçekleştirilmiştir. Veriler ile Y ve Z kuşak için regresyon modeli kurulmuş, diğer demografik değişkenlere göre t-test ve ANOVA analizleri gerçekleştirilmiştir. Korelasyon sonuçlarına göre Y kuşağı bağlamında müşteri memnuniyeti $(0,83)$ ve müşteri değeri $(0,77)$ ile tavsiye etme niyeti arasında güçlü ve pozitif ilişki bulunmaktadır. Korelasyon sonuçlarına göre $\mathrm{Z}$ kuşağı bağlamında müşteri memnuniyeti $(0,80)$ ve müşteri değeri $(0,74)$ ile tavsiye etme niyeti arasında güçlü ve pozitif ilişski bulunmaktadır. Y bağlamında müşteri memnuniyeti $(0,58)$ ve müşteri değerinin $(0,31)$ tavsiye etme niyetine etkisi olduğu belirlenmiştir. Z kuşağ bağlamında da müşteri memnuniyeti $(0,57)$ ve müşteri değerinin $(0,31)$ tavsiye etme niyetine etkisi olduğu belirlenmiştir. Bulgulara göre Hizmet kalitesi, operatör hakkında olumlu konuşma ve başkalarına operatörü söylemekten gurur duyma bağlamında kadınların algıları erkeklerin algılarına kıyasla daha fazladır.

Anabtar Kelimeler: Müşteri Memnuniyeti, Müşteri Değeri, Tavsiye Etme Niyeti, Telekomünikasyon

\section{Impact of Customer Satisfaction and Customer Value on Recommendation Intent in the} telecommunication sector

\begin{abstract}
Customer is the most important part for firms to continue their activities. Companies not only want to retain their customers, but they also want to provide services to potential customers by increasing their market shares. At this point, recommendation intention of existing customers, which is one of the most important advertising tools, is of great importance. Customers are more likely to recommend their friends, families and surroundings the company if they are satisfied and get customer value. In this perspective, this study is aimed to examine effect of customer satisfaction and customer value on recommendation intention according to demographic variables in the telecommunications sector in Turkey. Data were collected from generation Y and Z participants in Alanya district. Firstly, factor analysis of the scales was performed to use in the regression model. Regression model was established for $\mathrm{Y}$ and $\mathrm{Z}$ generations, $\mathrm{t}$-test and ANOVA analyzes were carried out according to other demographic variables. According to the correlation results, there is a strong and positive relationship between customer satisfaction (0.83) and customer value (0.77) with recommendation intention in the context of generation $Y$. There is a strong and positive relationship between customer satisfaction $(0.80)$ and customer value (0.74) with the recommendation intention in the context of generation $\mathrm{Z}$. In the generation Y context, it has been determined that customer satisfaction (0.58) and customer value $(0.31)$ have an effect on the recommendation intention. In the context of generation $Z$, it has been determined that customer satisfaction $(0.57)$ and customer value (0.31) have an effect on the recommendation intention. According to the findings, the perceptions of women in terms of service quality, positive word-of-mouth about the operator and being proud of telling others about the operator are higher than male.
\end{abstract}

Key Words: Customer Satisfaction, Customer Value, Recommendation Intention, Telecommunication

Atıf İçin / Please Cite As:

Karaman, D. (2021). Telekomünikasyon sektöründe müşteri memnuniyeti ve müşteri değerinin tavsiye etme niyetine etkisi. Manas Sosyal Arastirmalar Dergisi, 10(2), 1124-1137.

Geliş Tarihi / Received Date: 11.06.2020

Kabul Tarihi / Accepted Date: 22.02.2021

\footnotetext{
${ }^{1}$ Dr. Öğr. Üyesi - Alanya Alaaddin Keykubat Üniversitesi, Altso Myo, davut.karaman@alanya.edu.tr

(iD) ORCID: 0000-0001-9097-3460
} 


\section{Giriş}

Müşteri memnuniyetinin en önemli sonuçlarından biri müşterilerin aldıkları ürün / hizmet ile ilgili deneyimlerini ailesi, arkadaşları ve çevresi ile paylaşma (tavsiye etme veya etmeme) niyetidir. Bu noktada dikkat çeken unsur müşterilerin memnuniyetlerinden çok memnuniyetsizliklerini başkalarıyla paylaşma niyetinde olmasıdır (Vavra, 1997). Başka bir ifadeyle müşteriler ürün, hizmet veya işletme ile ilgili memnuniyetlerini çevreleriyle paylaştı̆̆ gibi memnuniyetsizliklerini de paylaşmaktadır (Dubrovski, 2001). Tavsiye etme haricinde memnun bir müşteri işletmenin ürün ve hizmetlerini tekrar satın alma eğiliminde olmakta ve sonuç olarak müşteri sadakati de geliştirilmektedir. Böylelikle, işletmelerin karlllı̆̆ ve pazar payı artarak diğer işletmelere kıyasla rekabet avantaj1 elde edebilmektedir (Wang, Lo, Chi ve Yang, 2004, s. 174).

Telekomünikasyon sektörü bağlamında, sadık müşterilerin uzun vadeli faydalara odaklanma ve her iki taraf için faydalı işbirliği eylemlerine girme olasıllğı daha yüksektir. Bununla birlikte, birçok telekomünikasyon sektörü sağlayıcısı teknolojik ilerlemelerin dinamik doğası ve İnternet ve e-ticaretin hılı gelişimi nedeniyle zorluklarla karşılaşmıştır (Wong, Cheng ve Yen, 2009). Hirata’ya göre (2019) tüketiciler istekleri ve paraları için değer gereksinimi konusunda sınırsız isteklere sahiptir. Telekomünikasyon hizmetlerinde bireysel kabulü ve benimsenmesi ile bu sınırsız isteklerin belirlenmesi ve karşılanması için konu tam olarak araştırılmamışır (Karnowski ve Jandura, 2014). Telekomünikasyon hizmetleri ile ilgili olarak, önceki araştırmalar (Danaher ve Rust, 1996; Gerpott, Rams ve Schindler, 2001; Wilfert, 1999, s. 191) müşteri değeri için üç özellik önermiştir. Bu özellikler; kapsama alanı (bağlantı kesintisiz hizmet), ödenen fiyat ve müşteri hizmetleri.

Müşteri memnuniyeti, tavsiye etme niyeti, müşteri değeri ve sadakat arasındaki ilişkileri ve etkilerini SPA sektöründe Setiowati ve Putri (2012), restoran sektöründe Jani ve Han (2014), turizm sektöründe Altunel ve Erkurt (2015), havalimanı sektöründe Tuncer ve Kızgin (2018) ve AVM sektöründe Alizadehfanaeloo ve Özüdoğru (2020) ele alarak araştırmışır. Telekomünikasyon sektörü bağlamında ise Işık (2011) müşteri memnuniyeti ve değeri, Yaşa ve Bozyiğit (2012) gelir ve GSM operatörü seçimini, Türker ve Türker (2013) marka sadakati yaratmada memnuniyet ve değeri, Alrwashdeh, Jahmani, Ibrahim ve Aljuhmani (2020) ise müşteri memnuniyeti ve tavsiye etme niyetini araştırmıştır. Telekomünikasyon sektörü bağlamında müşteri memnuniyeti konusu yoğun bir şekilde araştırılmış olmasına rağmen, bu sektörde memnuniyetin ve müşteri değerinin tavsiye etme niyetine etkisi konusu ele alınmamıştır. Bu kapsamda çalışmanın amacı olarak müşteri memnuniyeti ve müşteri değerinin tavsiye etme niyetine etkisinin Türkiye'deki telekomünikasyon sektöründe incelenmesi olarak belirlenmiştir. Ayrıca bu etkinin Y ve $Z$ kuşağı müşteriler için ayıı regresyon modelleri ile incelenmesi hedeflenmiştir.

\section{Literatür İncelemesi}

Müşterinin ürün / hizmet almadan önce sahip olduğu beklentileri ile satın alma veya deneyimleme sonrası algiladığı performans arasındaki fark memnuniyet olarak ifade edilmektedir (Oliver, 1980, s. 460). Müşteri memnuniyeti, müşteri tarafindan sağlayıcıdan alınan hizmetlerin bireysel özellikleri veya genel işlevselliği konusundaki beklentilerinin ne kadar yerine getirildiği konusunda yapılan deneyime dayalı bir değerlendirmedir (Homburg ve Bruhn, 1998). Müşteri memnuniyeti, bir hizmet sağlayıcısına karşı genel bir müşteri tutumu (Levesque ve McDougall, 1996, s. 14) ve müssteri beklentisi ile aldıkları arasındaki farklılıklara duygusal bir tepkidir (Zineldin, 2000). Genel bir ifadeyle müşteri memnuniyeti satın alma öncesi beklentiler ile satın alma sonrası elde edilenler arasındaki değerlendirmenin bir sonucudur (Eggert ve Ulaga, 2002; Kim, Minjeon ve Kandampully, 2007).

Müşteri memnuniyeti için iki farklı değerlendirme vardır: İlk kez satın alma sonrası değerlendirme (Mano ve Oliver, 1993) ve bir süre kullanıldıktan sonra genel değerlendirmenin toplam memnuniyeti (Fornell, 1992). Bundan dolayı müşteri memnuniyetinin en az iki farklı kavramsallaştırması vardır. Biri işleme özgüdür, diğeri birikimlidir (Andreassen, 2000). İşleme özgü bakış açısııla, müşteri memnuniyeti belirli bir satın alma olayının değerlendirilmesi olarak görülmektedir (Oliver, 1993). Öte yandan, kümülatif (birikimli) müşteri memnuniyeti, zaman içinde bir ürün veya hizmetle ilgili genel satın alma ve tüketim deneyimlerine dayanan bir değerlendirmedir (Anderson, Fornell ve Donald, 1994). Memnuniyet, müşterilerin işletmeye yönelik tutumlarını etkileyen faktörlerden biridir (Ranaweera ve Prabhu, 2003). Bundan dolayı, Garbarino ve Johnson (1999), memnuniyet ile işletmelerin müşterilerin tutumlarını önceden belirleyebileceğini ifade etmiştir. 
Müşterilerin satın alma öncesi var olan beklentilerini karşılayan veya daha fazlasını sunan işletmeler müşterilerini memnun etmiştir. Bu işletmeler müşteriler tarafından güvenilir ve kaliteli hizmet sağlayan işletmeler olarak görülmektedir (Mutlubaş ve Soybalı, 2017). Başka bir ifadeyle müşterinin satın alma öncesi var olan beklentileri ile sonrasındaki değerlendirmeleri arasındaki fark büyük olursa müşteri memnuniyeti düşük olacaktır (Saydan, 2008). Eğer işletmenin pazardaki ürün / hizmetleri müşteri memnuniyeti sağlamazsa, işletmenin pazardaki ürün / hizmetleri müşteriler tarafindan değersiz görülebilir (Kocabaş, 2017).

Shamsudin, Esa ve Ali (2019) memnun bir müşterinin deneyimlerini en az 4-6 kişi ile paylaşacağını belirtmektedir. Bu domino etkisi, müşteriyi elde tutma ile karşılaştırıldığında ve yeni müşteri arama maliyeti ile birleştiğinde, işletmenin kârını artırmaya yardımcı olacaktır. Yüksek düzeyde müşteri memnuniyetinin işletmeler için birçok faydası vardır. Örneğin, müşteri sadakatini arttırmakta, müşterilerin fiyat hassasiyetini azaltmakta, başarısız pazarlama ve yeni müşteri oluşturma maliyetlerini azaltmakta, müşteri sayısındaki artış nedeniyle işletme maliyetlerini azalmakta ve işletme itibarını arttırmaktadır (Kim, Park ve Jeong, 2004, s. 148). Bundan dolayı, müşterileri ile ilişkiler geliştirmek ve sadık müşteri kitlesi oluşturmak isteyen işletmelerin ilk hedefi müşteri memnuniyeti sağlamak olmalıdır (Belas ve Gabcova, 2014).

Değer, elde edilen genel faydalar ile müşteri tarafindan katlanılan fedakarlıklar arasında bir "değiştokuş" olarak tanımlanmaktadır (Lin, Sher ve Shih, 2005). Butz ve Goodstein (1996) müşterinin tedarikçinin ürettiği belirgin bir ürün veya hizmeti kullandıktan sonra, müşteri ile üretici arasında kurulan duygusal bağı değer olarak tanımlamaktadır. Müssteri değeri kavramı müşteri memnuniyeti kavramı ile sıkça karıştırlmaktadır. Müşteri memnuniyeti ile ilgili çalışmaların odak noktası ürün / hizmetler bağlamında müşterinin memnuniyet düzeyini arttırmaya yönelikken, müşteri değeri ile ilgili çalışmaların odak noktası benzer ürün / hizmeti sunan işletmeler arasında müşterilerin işletmeyi ve ürün / hizmeti nasıl seçtiğidir (Güler, 2009, s. 64).

Müşteri bakış açısıyla, müşteri değeri, “vazgeçmek” zorunda olduklarına (fedakarlıklar, maliyetler vb.) göre "elde ettikleri” (faydalar) değerlerdir (Zeithaml, 1988). Keller (1993) müşteri değeri kavramını müşterileri ürün / hizmete bağlayan ve yaratılan faydalar olarak tanımlamıştır. Hallowell (1996, s. 35) müşterinin algıladığı değeri satın aldığı ürün / hizmetten elde ettiği faydaları alternatif ürün / hizmetler ile karşılaştırması olarak ifade etmektedir. Woodruff (1997, s. 141) müşteri değerini "bir müşterinin hedeflerine ve amaçlarına ulaşmayı kolaylaştıran (veya engelleyen) ürün özelliklerinden, ürün performansından ve kullanımdan kaynaklanan sonuçların tercihi ve değerlendirmesi olarak" olarak tanımlamaktadır. Parasuraman'da (1997, s. 154) benzer bir tanımlama yapmıştır. Müşteri değeri ürün / hizmetin özelliklerinin, faydasının ve kalitesinin müşterinin beklentilerini ne düzeyde karşıladığı ile ilgili müşteri algısıdır (Parasuraman, 1997, s. 154). Holbrook (2005, s. 46) ise müşteri değerini "interaktif, göreceli tercih ve deneyim" olarak tanımlamıştır. Huang ve Zhang (2008, s. 102) bir işletmenin ürün / hizmetlerinin işlevselliği ve ikame edilebilirliğini müşteri değeri olarak kavramsallaştırmıştır. Benzer bir tanım olarak Gökdeniz ve Asık (2008, s. 134) müşteri değerini işletme imaj1, memnuniyet, fiyat ve kalite gibi soyut unsurlardan oluşan bir bütün olgu olarak tanımlamışır.

Müşteriler, tedarikçileri ve ürün / hizmetleri değerlendirmek için "ağızdan ağıza" iletişimi ve tavsiye etmeleri (referansları) önemli bilgi kaynakları olarak kullanmaktadır (Dawes, Dowling ve Patterson, 1991). Aydeniz ve Yüksel'e göre (2007, s. 108) ağızdan ağıza iletişim memnun edilmiş sadık müşteri yaratmakta önemli bir unsurdur. Hartline ve Jones (1996), değerin tavsiye niyetini olumlu yönde etkilediğini ifade emiştir. Tavsiye etme niyeti, yalnızca müşterinin tavsiye etme davranışını değil, aynı zamanda satın alma davranışını da tahmin etmenin en iyi ölçüsüdür (Reichheld, 2003). İşletme performansını müşteri memnuniyetinden daha iyi tahmin etmek için tavsiye etme niyetine bakılmalıdır (Keiningham, Cooil, Andreassen ve Aksoy, 2007).

Soderlund ve Ohman (2003) memnuniyetin tavsiye etme niyeti üzerindeki etkisinin, müşterinin niyet üzerindeki davranışları kontrol etme algisı ile ilişkili olduğunu belirtmiştir. Müşteriler yüksek düzeyde memnun kaldıklarında, değiş-tokuş işlemenin sonucunu olumlu olarak algılar ve bundan dolayı tedarikçiyi diğer tüketicilere tavsiye etmek için tekrar satın almaya istekli olurlar (Brown, Trevino ve Harrison, 2005). Tekrar satın alma ve tavsiye etme niyetlerini karşılaştıran Soderlund (2006) memnuniyetin, tekrar satın alma niyeti ve tavsiye etme niyeti üzerinde aynı etkiye sahip olmadığını ortaya çıkarmıştır. Tavsiye ve tekrar satın alma niyetleri, bir müşteri tarafindan farklı kontrol algılarına tabidir. Tekrar satın alma para harcama ile ilgilidir, tavsiye etme ise diğer insanlarla konuşarak övgü ile ilgilidir. Bundan dolayı tavsiye ve tekrar satın alma sadakatin iki sonucudur (Jin ve Su, 2009, s. 246). 
Müşteri memnuniyeti ile ilgili son yllarda yapılan çalşmalar memnun müşterilerin işletmeden daha fazla ürün / hizmet alacağ1 (Davras ve Caber, 2019, Razak ve Shamsudin, 2019), işletmeye güvenecek ve sadık müşteri olacakları (Hasim, Shamsudin, Ali ve Shabi, 2018), daha fazla ödeme yapacakları (Shamsudin vd., 2019) ve işletmeyi aile ve arkadaşlarına tavsiye ederek işletmeye yeni müşteriler kazandıracağ1 (Shamsudin ve Razali, 2015) sonucuna ulaşmıştır.

Uzkurt (2007), gerçekleştirdiği çalışmada müşteri memnuniyetinin ve müşteri değerinin satın alma sonrası müşteri eğilimlerine etkisini incelemiştir. Sonuçlara göre müşteri değerinin satın alma sonrası müşteri eğilimlerine etkisinde müşteri memnuniyetinin arac1 rolü olduğu belirlenmiştir. Uzkurt ve Torlak (2007), müşteri değeri yaratmada rakip ve müşteri odaklı olmanın etkisini araştırdıkları çalışmada müşteri odaklıllğın işletmelerin müşteri değeri yaratmasında anlamlı etkisi olduğu sonucuna varmışlardır.

Dündar ve Ecer (2008), öğrencilerin GSM operatörü seçiminde etkili olan faktörleri belirlemek amacıyla gerçekleştirdikleri çalışmada, bu faktörlerin hat fiyatı, konuşma fiyatı, ailenin GSM operatörü, kapsama alanı ve hizmet kalitesi olduğunu ifade etmiştir. Emir ve Çelik (2010), müşteri değeri yaratmada etkili olan unsurları incelemiştir. Sonuç olarak hijyen unsurunun müşteri değeri yaratmada en önemli unsur olduğu belirlenmiştir. Işı1k (2011) GSM operatörlerinde müşteri memnuniyeti, algıllanan değer, fiyat ve imaj konusunu incelediği çalışmada değişkenler arasında anlamlı ilişkiler olduğu sonucuna ulaşmıştır.

Setiowati ve Putri (2012), SPA sektöründe Endonezya'da müşteri memnuniyetini ve müşteri sadakatini etkileyen algılanan değerin beş boyutunun etkisini araştırmış ve algılanan değer, müşteri tavsiyesine ve tekrar satın alımına yol açan müşteri bağlliğının göstergelerinden biri olduğu belirlenmiştir. Yaşa ve Bozkurt (2012) gelir, cep telefonu markası ve kullanılan GSM operatörü arasındaki ilişkiyi Y kuşağından elde ettiği veri ile araştırmıstır. Sonuç olarak gelir ile kullanılan GSM operatörü arasında anlamlı ilişki bulunamazken, gelir ile cep telefonu markası arasında anlamlı ilişki olduğu belirlenmiştir.

Altunel (2013), müşteri memnuniyetinin tavsiye etme niyeti ve algilanan değer arasındaki aracı rolünü incelediği çalışmada müşteri memnuniyetinin tavsiye etme niyeti ve algılanan değer arasındaki aracı role sahip olduğu sonucuna ulaşmıştır. Türker ve Türker (2013) GSM operatörlerinde marka sadakati yaratmada müşteri memnuniyeti, değer ve güven faktörlerinin rolünü incelemiştir. Sonuç olarak değişkenlerin marka sadakatine önemli etkilerinin olduğu belirlenmiştir.

Jani ve Han (2014), gerçekleştikleri çalışmada müşteri ihtiyaçlarını karşılamanın restoran müşterilerinin tavsiye etme niyetini olumlu yönde etkilediği sonucuna ulaşmıştır. Hassan, Ramayah ve Maghsoudi (2015), gelişmekte olan ülkelerde e-yaşam tarzının mobil tüketicilerin müşteri memnuniyeti ve sadakati üzerindeki etkisini Y kuşağından toplanan verilerle incelemiştir. Sonuçlara göre e-yaşam tarzının müşteri memnuniyeti ve sadakat üzerinde önemli bir etkiye sahip olduğunu göstermiştir. Altunel ve Erkurt (2015), kültürel turizm destinasyonu bağlamında katılım ve tavsiye niyeti arasındaki ilişki üzerinde deneyim kalitesi ve memnuniyetinin aracılık etkisini incelemiş ve sonuçlar, deneyim kalitesi ve memnuniyetinin, kültür turizmi bağlamında katılım ve tavsiye niyeti arasındaki ilişkiye aracılık ettiğini ortaya çıkarmıştır.

Tuncer ve Kızgın (2018) havalimanı sektöründe yolcuların tavsiye etme niyetini incelemiştir. Sonuçlara göre tavsiye etme niyetine oturma alanları, terminal personeli ve yönlendirici işaretlerin etkisi bulunmaktadır. Alrwashdeh vd. (2020), kullanıcı memnuniyetini ve e-WOM’u geliştiren ve iyileştiren algilanan telekomünikasyon hizmet kalitesi ve algılanan değer boyutlanna dayanarak, hizmet kalitesinin algılanan değer boyutları üzerindeki etkilerini ampirik olarak araştırmıştır. Kuzey Kıbrıs’taki mobil operatörler bağlamında hizmet kalitesinin algılanan değer boyutları üzerinde etkisi olduğu belirlenmiştir. Alizadehfanaeloo ve Özüdoğru (2020), AVM sektöründe müşteri memnuniyetinin tekrar ziyaret etme ve tavsiye etme niyetine etkisini araştırmış ve sonuç olarak müşteri memnuniyetinin tekrar ziyaret etme ve tavsiye etme niyetine pozitif etkisi olduğu belirlenmiştir.

\section{Yöntem}

Müşteri değeri ve müşteri memnuniyetinin tavsiye etme niyetine etkisinin demografik özelliklere göre incelenmesi amacıyla hazırlanan temel araştırma modeli Şekil 1'de verilmiştir. Literatür ve yapılan araştırmalar göz önünde bulundurularak araştırmada toplam 6 hipotez geliştirilmiştir. Bu hipotezler;

$\mathrm{H}_{1}$ : Y kuşağı bağlamında müşteri memnuniyeti ve müşteri değerinin tavsiye etmeye etkisi vardır.

$\mathrm{H}_{2}: \mathrm{Z}$ kuşağı bağlamında müşteri memnuniyeti ve müşteri değerinin tavsiye etmeye etkisi vardır. 
$\mathrm{H}_{3}$ : Y ve $\mathrm{Z}$ kuşağının müşteri memnuniyeti, müssteri değeri ve tavsiye etme niyeti ifadelerine olan algıları farklılaşmaktadır.

$\mathrm{H}_{4}$ : Cinsiyete göre müşteri memnuniyeti, müşteri değeri ve tavsiye etme niyeti ifadelerine olan algıları farklılassmaktadır.

$\mathrm{H}_{5}$ : Kullanılan operatörlerin kullanım yılına göre katılımcıların ifadelere olan algıları farklılaşmaktadır.

$\mathrm{H}_{6}$ : Katılımcıların kullandıkları GSM operatörünü değiştirme isteyip istememesine göre katıllımcıların ifadelere olan algıları farklılaşmaktadır.

Çalışmanın hipotezlerini test etmek için 5'li Likert ile hazırlanan anket kullanılmıştır. Anket toplam dört bölümden oluşmaktadır. İlk bölümünde katılımcıların demografik özelliklerine ilişkin (cinsiyet, doğum yll, kullanılan GSM operatörü, operatörü kullanma yllı, başka operatöre geçme isteği) ifadeler bulunmaktadır. Anketin ikinci bölümde müşteri memnuniyeti, üçüncü bölümde müşteri değeri ve dördüncü bölümde ise tavsiye etmene niyeti ölçekleri bulunmaktadır. Müşteri memnuniyetini ölçmek için Şendur (2009) tarafindan Eggert ve Ulaga (2002); McDougall ve Levesque (2000) ve Oliver (1980) çalısmalarından uyarlanan geçerliliği ve güvenilirliği kanıtlanmış “müşteri memnuniyeti” ölçeği kullanılmıştır. Müş̧eri değerini ölçmek için Şendur (2009) tarafindan Eggert ve Ulaga (2002); McDougall ve Levesque (2000) ve Petrick (2004) çalışmalarından uyarlanan geçerliliği ve güvenilirliği kanıtlanmış "müşteri değeri” ölçeği kullanılmıştır. Tavsiye etme niyetini ölçmek için Tavukçu (2019) tarafindan Babin, Lee, Kim ve Griffin (2005); Goyette, Ricard, Bergeron ve Marticotte (2010); Hennig-Thurau, Gwinner ve Gremler (2002); Nusair, Parsa ve Cobanoglu, (2011); Silverman (2001) ve Teo ve Soutar (2012), çalışmalarından uyarlanan geçerliliği ve güvenilirliği kanıtlanmış "tavsiye etme niyeti” ölçeği kullanılmıştır. Müşteri memnuniyeti ölçeği 4 ifadeden oluşmaktadır ve Croanbach Alpha (CA) değeri 0,89'dur. Müşteri değeri ölçeği 3 ifadeden oluşmaktadır ve CA değeri 0,85 'dir. Tavsiye etme ölçeği ise 5 ifadeden oluşmaktadır ve CA değeri 0,91'dir. CA değerleri 0,60'dan fazla olmasından dolayı ölçeklerin güvenilir olduğu söylenebilir (Kalayc1, 2014).
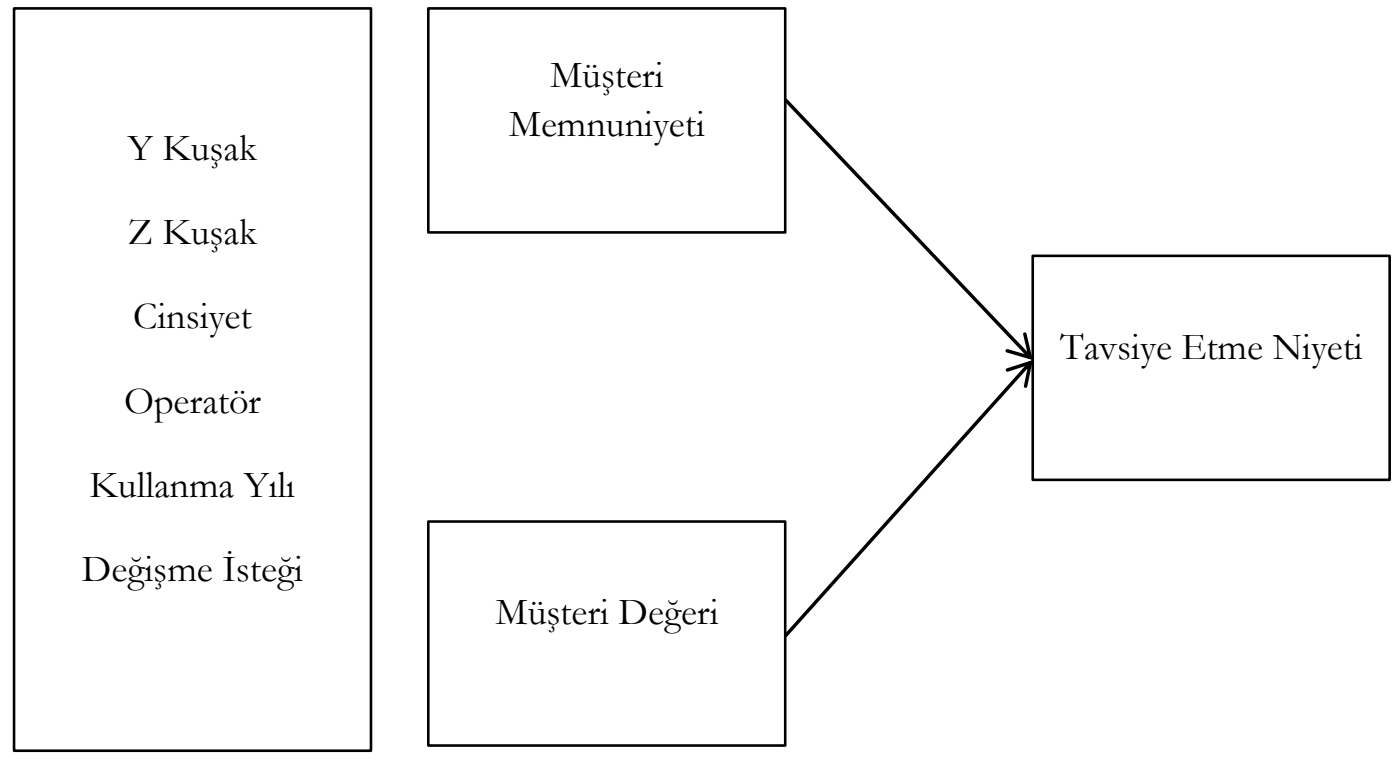

Şekil 1. Arastırma Modeli

Araştırma evrenini Antalya destinasyonu Alanya ilçesi yerel halkı oluşturmaktadır. Alanya ilçesinin TÜIK verilerine göre 2018 yılı nüfusu 327.503'dür. Büyük örneklemler için 0.05 örneklem hatası ile ana kütleyi temsil gücüne sahip örneklem grubunun (n) 384'dir (Yazıcıŏglu ve Erdoğan, 2004). Çalışma gönüllülük esasına dayanmaktadır. Bundan dolayı anketler kolayda örneklem yöntemi ile $\mathrm{Y}$ ve $\mathrm{Z}$ kuşağa uygulanmıştır. Toplam 662 anket ile çalışma gerçekleştirilmiştir. Veriler Kasım-Aralık 2019 tarihinde toplanmıştır. Veriler ile $\mathrm{Y}$ ve $\mathrm{Z}$ kuşak için regresyon modeli kurulmuş, diğer demografik değişkenlere göre t-test ve ANOVA analizleri gerçekleştirilmiştir. 


\section{Bulgular}

Katılımcıların demografik özellikleri ile ilgili yapılan frekans analizi sonuçları Tablo 1'de verilmiştir. Tablo 1'de görüldügüü üzere katılımciların \% 44'ü erkek ve \% 56'sı kadındır. Katılımcıların doğum yllı kuşaklar bağlamında incelendiğinde \% 61'i Y Kuşağı ve \% 39’u Z kuşağı katılımcıdır. Hizmet alınan GSM operatörü incelendiğinde ise katılımcıların \% 30,8'i Turkcell, \% 29,5’i Vodafone ve \% 39,7'si Türk Telekom GSM operatörlerinden hizmet almaktadır. Katılımcıların \% 19,6's1 '1 yıldan daha az', \% 28,9'u '13 yıl' ve $\%$ 51,5' ' ' 3 yıldan fazla' yildır kullandıkları GSM operatöründen hizmet almaktadır. Katılımcıların \% 25,2'sinin başka bir operatöre geçme niyeti varken, geri kalan katılımcılar kullandıkları operatörü değiştirmek istememektedir. Katılımcıların \% 36,2'si GSM operatörünü herhangi bir reklam kanalından takip etmemektedir. Katılımcıların \% 6,5’i televizyondan, \% 28,1’i sosyal medyadan ve \% 29,2'si diğer ortamlardan GSM operatörlerinin reklamlarını takip etmektedir.

Tablo 1. Katllimcllarn Demografike Özelikleri

\begin{tabular}{llll}
\hline \multicolumn{1}{c}{ Değişkenler } & Demografi & Say1 & Frekans (\%) \\
\hline \multirow{2}{*}{ Cinsiyet } & Erkek & 291 & 44,0 \\
& Kadın & 371 & 56,0 \\
\hline \multirow{2}{*}{ Kuşak } & Y & 404 & 61,0 \\
& Z & 258 & 39,0 \\
\multirow{2}{*}{ Kullanılan GSM Operatörü } & Turkcell & 204 & 30,8 \\
& Vodafone & 195 & 29,5 \\
\hline \multirow{2}{*}{ Kaç Yıldır Bu GSM Operatörünü } & Türk Telekom & 263 & 39,7 \\
Kullanıorsunuz? & 1 ylldan daha az & 130 & 19,6 \\
& $1-3$ yll & 191 & 28,9 \\
Başak GSM Operatörüne Geçmek İster & 3 ylldan fazla & 341 & 51,5 \\
\hline \multirow{2}{*}{ misiniz? } & Evet & 167 & 25,2 \\
GSM Operatörünün Reklaminı Hangi & Hayır & 495 & 74,8 \\
Kanallardan Takip Ediyorsunuz? & TV & 43 & 6,5 \\
& Sosyal Medya & 186 & 28,1 \\
& Diğer & 193 & 29,2 \\
\hline
\end{tabular}

Regresyon modeli için öncelikle müşteri memnuniyeti, müşteri değeri ve tavsiye etme niyeti ölçekleri faktör analizine tabi tutulmuştur. Üç ölçekteki ifadelerin faktör yükleri, KMO ve toplam varyans açılama oranları Tablo 2'de verilmiştir.

Tablo 2. Ölçeklerin Faktör Analiz̧i Değerleri

\begin{tabular}{|c|c|c|c|}
\hline İfadeler & 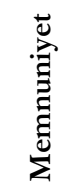 & 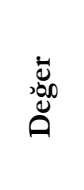 & 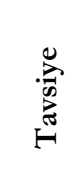 \\
\hline $\begin{array}{l}\text { Kullandığım operatörümün hizmetleri beni her yönüyle tatmin ediyor. } \\
\text { Kullandığım operatörümün diğer operatörlere göre daha iyi olduğunu düşünüyorum. } \\
\text { Diğer operatörlere kıyasla operatörünü tercih etmekle doğru bir iş yaptığımı düşünüyorum. } \\
\text { Kullandığım operatörümün hizmetleri beklentilerimi tamamen karşılamaktadır } \\
\text { Her şey dikkate alındığında operatörünüzün hizmetlerini nasıl değerlendiriyorsunuz } \\
\text { Bir bütün olarak düşündüğ̈ünüzde operatörünüzün hizmet kalitesini nasıl } \\
\text { değerlendiriyorsunuz } \\
\text { Her şey dikkate alındığında operatörünüzün hizmet kalitesini nasıl değerlendiriyorsunuz } \\
\text { İnsanlara operatörüm hakkında olumlu şeyler söylerim. } \\
\text { Başkalarına, bu operatörü kullandığımı söylemekten gurur duyarım } \\
\text { Bu operatörü, arkadaşlarıma ve çevremdekilere öneririm. } \\
\text { Bu operatör hakkında, diğer operatörler hakkında konuştuğumdan daha fazla konuşurum } \\
\text { Bu operatör hakkında, cevremdekilere her zaman olumlu șeyler anlatırım }\end{array}$ & $\begin{array}{l}, 849 \\
, 868 \\
, 894 \\
, 853\end{array}$ & $\begin{array}{l}, 918 \\
, 912 \\
, 796\end{array}$ & $\begin{array}{l}, 879 \\
, 864 \\
, 907 \\
, 783 \\
, 851\end{array}$ \\
\hline $\begin{array}{r}\text { KMO } \\
\text { Toplam Varyans Açıklama (\%) } \\
\text { CA }\end{array}$ & $\begin{array}{c}797 \\
75,01 \\
, 89 \\
\end{array}$ & $\begin{array}{c}, 677 \\
76,96 \\
, 85 \\
\end{array}$ & $\begin{array}{c}, 884 \\
73,58 \\
, 91\end{array}$ \\
\hline
\end{tabular}


Tavşancıl'a (2010) göre KMO değerinin 1'e yaklaştıkça mükemmel ve 0,50'nin altına düşünce ise kabul edilmez olduğu varsayılmaktadır. Tablo 2 incelendiğinde KMO değerinin iyi olduğu görülmektedir. KMO değerinin faktör analizinde 1'e yakın olması çalışmadaki örneklem büyüklüğünün faktör analizi için uygun olduğunu desteklemektedir (Otrar ve Arg1n, 2015). Ölçeklerin toplam varyans açıklama oranları \% 75 üzeridir. Ayrıca ölçeklerdeki ifadelerin faktör yüklerinin 0,800 üzeri olması ifadelerin ölçeği temsil ettiğini göstermektedir (Zeller ve Karmines, 1978). CA değerlerinin ise 0,60’tan fazla olması ölçeklerin güvenilir ve iç tutarlığa sahip olduğu göstermektedir (Kalayc1, 2014).

Araştırmanın ilk hipotezi olan müşteri memnuniyeti ve müşteri değerinin tavsiye etme niyetine etkisini $\mathrm{Y}$ ve $\mathrm{Z}$ kuşak bağlamında belirlemek için iki ayrı regresyon modeli kurulmuştur. Y kuşağı için değişkenler arası korelasyon sonuçları Tablo 3’te verilmiştir.

Tablo 3. Y kuşăğ İ̧̧in Değğskeenler Arası Korelasyon

\begin{tabular}{llll}
\hline & Tavsiye & Memnuniyet & Değer \\
\hline Tavsiye & 1,00 & & \\
Memnuniyet & 0,83 & 1,00 & 1,00 \\
Değer & 0,77 & 0,79 & \\
\hline
\end{tabular}

Tablo 3'de görüldüğü üzere tavsiye etme niyeti ile müşteri memnuniyeti arasında müşteri değerine göre daha fazla ilişki bulunmaktadır. Korelasyon sonuçlarına göre $Y$ kuşağı bağlamında müşteri memnuniyeti, müşteri değeri ve tavsiye etme niyeti arasında güçlü ve pozitif ilişki bulunmaktadır. Y kuşağ1 için kurulan regresyon modelinin standardize ve t-değeri sonuçları Şekil 2'de verilmiştir.
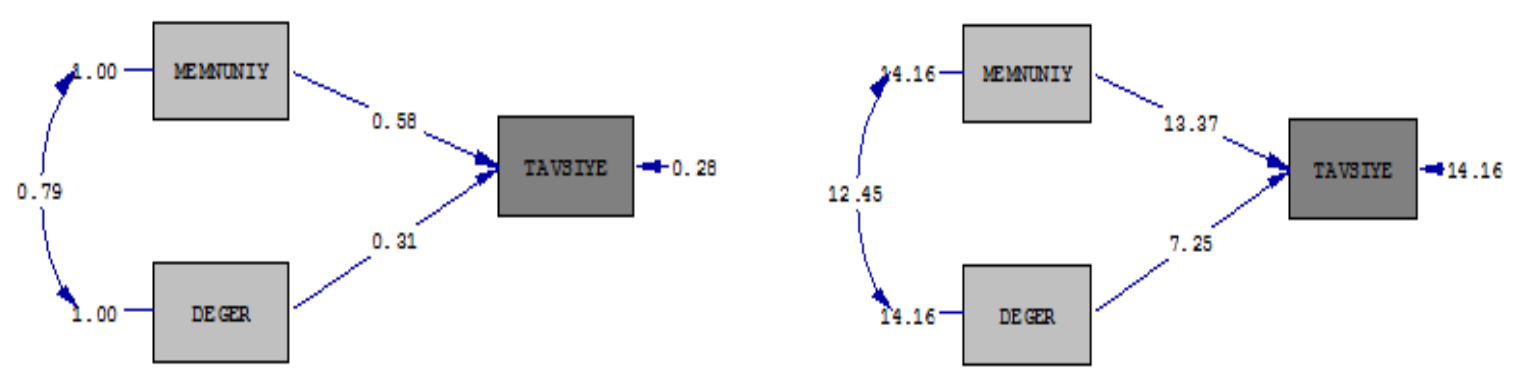

Standardize Edilmiş Değerler

$$
\text { t-değerleri }
$$

\section{Şekil 2. Y Kuşă̆ İçin Regresyon Modeli}

Şekil 2'de verildiği gibi Y kuşağı bağlamında müşteri memnuniyeti ve müşteri değerinin tavsiye etme niyetine etkisi vardır. Bundan dolayı $\mathrm{H}_{1}$ kabul edilmiştir. En çok etki eden değişken ise müşteri memnuniyetidir. Modelin R²'si 0,72 olup Y kuşağı için yapısal eşitlik şu şekildedir;

$$
\text { Tavsiye Etme Niyeti }=0,58 * \text { Memnuniyet }+0,31 * \text { Değer }
$$

Araştırmada geliştirilen $\mathrm{H}_{2}$ kapsamında, müşteri memnuniyeti ve müşteri değerinin tavsiye etme niyetine etkisini Z kuşak bağlamında belirlemek için kurulan regresyon modelinin değişkenler arası korelasyon sonuçları Tablo 4'te verilmiştir. Tablo 4'de görüldüğü üzere tavsiye etme niyeti ile müşteri memnuniyeti arasında müşteri değerine göre daha fazla ilişki bulunmaktadır. Korelasyon sonuçlarına göre Z kuşağ1 bağlamında müşteri memnuniyeti, müşteri değeri ve tavsiye etme niyeti arasında güçlü ve pozitif ilişki bulunmaktadır.

Tablo 4. Z kuşă̆ İçin Değişskenler Arası Korelasyon

\begin{tabular}{llll}
\hline & Tavsiye & Memnuniyet & Değer \\
\hline Tavsiye & 1,00 & & \\
Memnuniyet & 0,80 & 1,00 & 1,00 \\
Değer & 0,74 & 0,76 & \\
\hline
\end{tabular}

Z kuşağ1 için kurulan regresyon modelinin standardize ve t-değeri sonuçları Şekil 3'de verilmiştir. Şekil 2'de verildiği gibi Z kuşağı bağlamında müşteri memnuniyeti ve müşteri değerinin tavsiye etme niyetine etkisi vardır. Bundan dolayı $\mathrm{H}_{2}$ kabul edilmiştir. En çok etki eden değişken ise müşteri memnuniyetidir. Modelin R2'si 0,69 olup Z kuşağı için yapısal eşitlik şu şekildedir; 

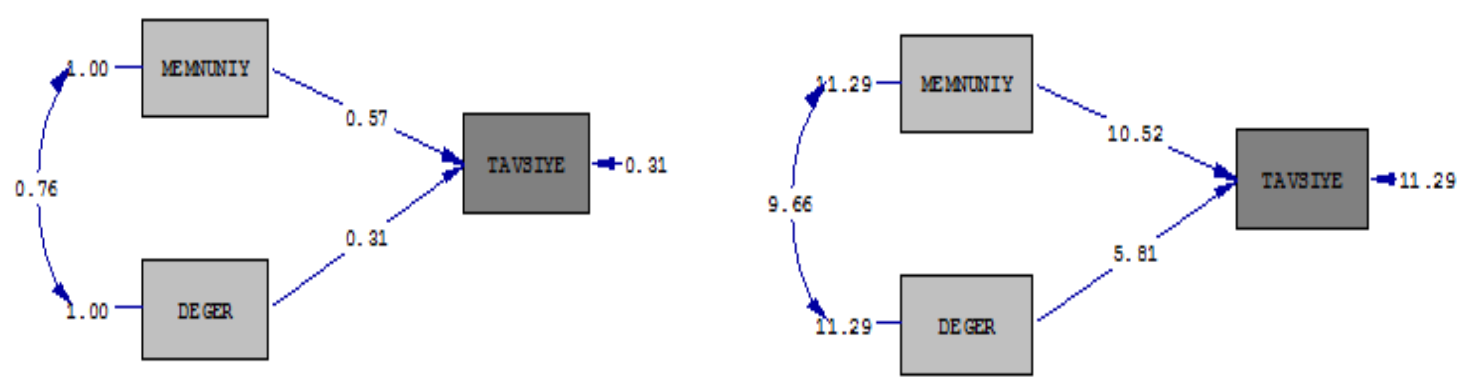

Standardize Edilmiş Değerler

t-değerleri

Şekil 3. Z Kuşă̆ İ̧̧in Regresyon Modeli

Araştırmada $\mathrm{H}_{3}$ olarak yer alan, $\mathrm{Y}$ ve $\mathrm{Z}$ kuşağı katılımcılar arasında müşteri memnuniyeti (MM), müşteri değeri (MD) ve tavsiye etme niyeti (TE) ifadeleri için alg1 farkı olup olmadığını belirlemek için gerçekleştirilen t-test sonuçlarına göre herhangi bir ifade de alg1 fark1 bulunamamıştır. Boyutlar bağlamında yapilan t-test sonucuna göre de $\mathrm{Y}$ ve $\mathrm{Z}$ kuşağ 1 katıllımcılar arasında müşteri memnuniyeti (MM), müşteri değeri (MD) ve tavsiye etme niyeti (TE) boyutları için alg1 farkı bulunmamıştır. Bundan dolayı $\mathrm{H}_{3}$ kabul edilmemiştir Cinsiyete göre yapılan t-test analizi sonucunda göre üç ifadede alg1 farkı olduğu belirlenmiştir. Cinsiyete göre alg1 fark1 olan ifadeler Tablo 5'de verilmiştir.

Tablo 5. Cinsiyet Göre Algz Farklar

\begin{tabular}{|c|c|c|c|c|c|}
\hline \multirow{2}{*}{ Değişken } & \multirow{2}{*}{ İfadeler } & \multicolumn{2}{|c|}{ Ortalamalar } & \multirow{2}{*}{ F değeri } & \multirow{2}{*}{ P değeri* } \\
\hline & & Erkek & Kadın & & \\
\hline $\mathrm{MD}$ & $\begin{array}{l}\text { Her şey dikkate alındığında operatörünüzün hizmet kalitesini nasıl } \\
\text { değerlendiriyorsunuz }\end{array}$ & 3,22 & 3,47 &, 102 &, 002 \\
\hline TE & İnsanlara operatörüm hakkında olumlu şeyler söylerim. & 3,16 & 3,37 &, 145 & 010 \\
\hline TE & Başkalarına, bu operatörü kullandığımı söylemekten gurur duyarım & 3,09 & 3,33 &, 528 & 004 \\
\hline
\end{tabular}

Not: \%5 önem düzeyinde istatistiki olarak anlamllhk * işareti ile gösterilmistir.

Tablo 5'de görüldügüü üzere alg1 farkı olan ifadelerden biri müşteri değeri diğer ikisi tavsiye etme niyeti ile ilgilidir. Boyutlar kapsamında gerçekleştirilen cinsiyete göre t-test analizi sonuçlarnna göre ise müşteri değeri $(\mathrm{p}=, 022 ; \mathrm{t}=-2,292 ; \mathrm{F}=, 737)$ ve tavsiye etme niyeti $(\mathrm{p}=, 012 ; \mathrm{t}=-2,512 ; \mathrm{F}=, 212)$ boyutlarında alg1 farkları olduğu belirlenmiştir. Bundan dolayı $\mathrm{H}_{4}$ kabul edilmiştir. Hizmet kalitesi, operatör hakkında olumlu konuşma ve başkalarına operatörü söylemekten gurur duyma bağlamında kadınların algıları erkeklerin algılarına kıyasla daha fazladır. Kullanılan operatöre göre katılımcıların ifadelere olan algı farklarını belirlemek amacıyla geliştirilen $\mathrm{H}_{5}$ için ANOVA analizi gerçekleştirilmiştir. Analiz sonucunda bütün ifadelerde alg1 farkı olduğu belirlenmiştir. Bundan dolayı $\mathrm{H}_{5}$ kabul edilmiştir.

Katılımciların operatörlerini kullanma yllına göre ifadelere olan alg1 farklarını belirlemek amacıyla geliştirilen $\mathrm{H}_{6}$ için ANOVA analizi gerçekleştirilmiştir. Toplam 7 ifade de alg1 farkı olduğu belirlenmiştir. Boyutlar temelinde katılımcıların operatörlerini kullanma yılına göre gerçekleştirilen ANOVA analizi sonuçlarına göre de müşteri değeri $(F=11,621 ; p=, 000)$, müşteri memnuniyeti $(F=13,286 ; p=, 000)$ ve tavsiye etme niyeti $(\mathrm{F}=12,181 ; \mathrm{p}=, 000)$ boyutlarına algı farkları olduğu belirlenmiştir. Bundan dolayı $\mathrm{H}_{6}$ kabul edilmiştir. Sonuçlar Tablo 6'da özetlenmiştir.

Alg1 farklarının hangi gruplar arasında olduğunu belirlemek için Tukey testi gerçekleştirilmiştir. Tukey Tamhane testine göre "insanlara operatörüm hakkında olumlu şeyler söylerim" ifadesinde belirlenen alg1 farkı gruplar arasında anlamsızdır. Diğer 6 ifadedeki algı farkı sonuçları şu şekilde özetlenebilir;

- 1-3 yıldır aynı operatörü kullanan katılımcıların "kullandığım operatörümün diğer operatörlere göre daha iyi olduğunu düşünüyorum" ve "diğer operatörlere kiyasla operatörünü tercih etmekle doğru bir iş yaptığımı düşünüyorum" ifadelerine olan algısı 3 yıldan fazla aynı operatörü kullanan katılımciların algisından düşüktür,

- 1-3 yıldır aynı operatörü kullanan katılımciların "kullandığım operatörümün hizmetleri beklentilerimi tamamen karşılamaktadır" ifadesine olan algısı 1 yıldan az ve 3 yıldan fazla aynı operatörü kullanan katılımciların algısından düşüktür, 
- 1-3 yıldır aynı operatörü kullanan katılımcıların "her şey dikkate alındığında operatörünüzün hizmetlerini nasıl değerlendiriyorsunuz”, "bir bütün olarak düşündügünüzde operatörünüzün hizmet kalitesini nasıl değerlendiriyorsunuz" ve "başkalarına, bu operatörü kullandı̆̆ımı söylemekten gurur duyarım” ifadelerine olan alg1sı 3 yıldan fazla aynı operatörü kullanan katılımcıların algisından düşüktür.

Tablo 6. Operatörü Kullanma Yulına Göre Alg̨ Farkları (Yil)

\begin{tabular}{|c|c|c|c|c|c|c|}
\hline \multirow{2}{*}{ Değişken } & \multirow{2}{*}{ İfadeler } & \multicolumn{3}{|c|}{ Ortalamalar } & \multirow{2}{*}{ F değeri } & \multirow{2}{*}{ P değeri* } \\
\hline & & $<1$ & $1-3$ & $3>$ & & \\
\hline MM & $\begin{array}{l}\text { Kullandığım operatörümün diğer operatörlere göre daha } \\
\text { iyi olduğunu düşünüyorum }\end{array}$ & 3,27 & 3,11 & 3,43 & 5,270 & ,005 \\
\hline MM & $\begin{array}{l}\text { Diğer operatörlere kiyasla operatörünü tercih etmekle } \\
\text { doğru bir iş yaptı̆̆ımı düşünüyorum }\end{array}$ & 3,43 & 3,23 & 3,51 & 4,072 & 017 \\
\hline MM & $\begin{array}{l}\text { Kullandığım operatörümün hizmetleri beklentilerimi } \\
\text { tamamen karşılamaktadır }\end{array}$ & 3,20 & 2,88 & 3,15 & 4,421 & 012 \\
\hline MD & $\begin{array}{l}\text { Her şey dikkate alındığında operatörünüzün hizmetlerini } \\
\text { nasıl değerlendiriyorsunuz }\end{array}$ & 3,42 & 3,21 & 3,41 & 3,478 & 031 \\
\hline MD & $\begin{array}{l}\text { Bir bütün olarak düşündüğünüzde operatörünüzün } \\
\text { hizmet kalitesini nasıl değerlendiriyorsunuz }\end{array}$ & 3,23 & 3,26 & 3,50 & 4,833 & ,008 \\
\hline $\mathrm{TE}$ & İnsanlara operatörüm hakkında olumlu şeyler söylerim & 3,33 & 3,13 & 3,34 & 3,101 & ,046 \\
\hline $\mathrm{TE}$ & $\begin{array}{l}\text { Başkalarına, bu operatörü kullandığımı söylemekten gurur } \\
\text { duyarım }\end{array}$ & 3,23 & 3,05 & 3,32 & 3,987 & ,019 \\
\hline
\end{tabular}

Not: \%5 önem düzeyinde istatistiki olarak anlamlllk * isareti ile gösterilmistir.

Katılımcıların kullandıkları GSM operatörünü değiştirme isteyip istememesine göre alg1 farklarını belirlemek için $\mathrm{t}$-test sonucuna göre tüm ifadelerde alg1 farkı bulunduğu belirlenmiştir. Kullandığ1 operatörü değiştirmek istemeyenlerin tüm ifadelere algısı değiştirmek isteyenlere kıyasla daha fazladır. Bundan dolayı operatörünü değiştirmek istemeyen katıllmcıların doğal olarak memnun edilmiş ve değer yaratılmış müşteriler olduğu ve tavsiye etme eğilimde oldukları söylenebilir.

\section{Sonuç, Tartışma ve Öneriler}

Araştırma kapsamında gerçekleştirilen analiz sonuçlarında, Y ve Z kuşağı bağlamında müşteri memnuniyeti, müşteri değeri ve tavsiye etme niyeti arasında güçlü ve pozitif ilişki belirlenmiştir. Bu sonuçlar; konu ile ilgili farklı sektörlerde araştırmalar geliştiren Alizadehfanaeloo ve Özüdoğru (2020); Altunel (2013); Brown vd. (2005); Hartline ve Jones (1996); Jani ve Han (2014) ile Soderlund ve Ohman'n (2003) çalışmaları ile benzerlik göstermektedir. Müşteri memnuniyetinin müşteri değerinden daha çok tavsiye etme niyetine etkisi olduğundan dolayı GSM operatörlerinin öncelikle müşteri memnuniyetine önem vermesi gerekmektedir. Değişkenler arasında güçlü korelasyon olduğundan dolayı GSM operatörlerinin tavsiye edilmelerini arttırmak, diğer bir ifadeyle olumlu ağızdan ağıza iletişsim için müşteri memnuniyeti ve müşteri değeri stratejileri geliştirmelidir. Müşteri memnuniyeti ve müşteri değeri için uygulanan stratejilerin verimliliği belirli periyotlarda müşteriler izlenerek ölçülmeli, varsa sorunlar ağızdan ağıza iletişim ile yayılmadan önce giderilmelidir.

$Y$ ve $Z$ kuşağı bağlamında müşteri memnuniyeti ve müşteri değerinin tavsiye etme niyetine etkisi olduğu bulunmuştur. Z kuşağı için memnuniyetin daha etkili bir değişken olduğu belirlenmiştir. Kuşaklar bağlamında yapılan kısıtlı çalışma mevcuttur. Bundan dolayı tartışma yapılabilmesi için GSM sektörü ile ilgili daha fazla çalısma yapılması önerilmektedir.

Cinsiyete göre üç ifadede, operatörü kullanma yılına göre altı ifadede alg1 farkı olduğu belirlenmiştir. Boyutlar kapsamında gerçekleştirilen cinsiyete göre t-test analizi sonuçlarına göre ise müşteri değeri $(\mathrm{p}=, 022 ; \mathrm{t}=-2,292 ; \mathrm{F}=, 737)$ ve tavsiye etme niyeti $(\mathrm{p}=, 012 ; \mathrm{t}=-2,512 ; \mathrm{F}=, 212)$ boyutlarında alg1 farklar1 olduğu belirlenmiştir. Benzer şekilde Atmaca ve Keskin (2014) müşteri memnuniyetinin abonelerin kullandıkları operatöre göre değişkenlik gösterdiğini belirlemiştir. Kullanılan operatöre göre tüm ifadelerde alg1 farkı bulunmuştur. Boyutlar temelinde katılımcıların operatörlerini kullanma yılına göre gerçekleştirilen ANOVA analizi sonuçlarına göre de müşteri değeri ( $\mathrm{F}=11,621 ; \mathrm{p}=, 000)$, müşteri memnuniyeti $(\mathrm{F}=13,286$; $\mathrm{p}=, 000)$ ve tavsiye etme niyeti $(\mathrm{F}=12,181 ; \mathrm{p}=, 000)$ boyutlarına alg1 farkları olduğu belirlenmiştir. Kullanılan operatör bağlamında ifadelerin ortalamaları incelenince tüm ifadelerde Turkcell kullanıcılarının algısının diğer operatörlerin kullanıcılarının algısından daha fazla olduğu belirlenmiştir. Aktepe ve Baş'ın (2008) yaptığı çalışmada da Turkcell’in rakiplerine göre çok avantajlı konumda olduğu sonucuna ulaşılmıştır. Erkek müşterilere yönelik uygulamalarla hizmet kalitesini arttırarak tavsiye etme ile ilgili 
niyetleri sağlanmalıdır. 1-3 yıl arası kullanıcı olan müşterilerin alg1ları 3 yıl üzerinden düşüktür. Bundan dolayı GSM operatörleri yeni müşterilerini elde tutabilmek için ilk 3 ylla özel uygulamalar, stratejiler ve politikalar geliştirmelidir.

Katılımcıların kullandıkları GSM operatörünü değiştirme isteyip istememesine göre katılımcıların ifadelere olan algıları farklılaşmaktadır. Kullanım yılına göre belirlenen algı farkları Arasıl, Karaçuha, Özer ve Aydın'ın (2004) ifadelerini destekler niteliktedir. GSM sektöründe abonelere sunulan hizmetin süreklilik arz etmesi, bu sektörde abonenin sunulan hizmetle ilgili olarak genel algisının herhangi bir anda alınan hizmetten duyulan memnuniyet ya da memnuniyetsizliğe göre değil, abone olduğu süre içerisinde aldığ1 hizmete göre değerlendirmesine neden olacaktır (Arasıl vd., 2004). Benzer şekilde, tavsiye etme niyeti için Olaru, Purchase ve Peterson (2008) işletmeyi başkalarına tavsiye etmek için değerin öneminin daha uzun vadeli sözleşmeler için daha yüksek olduğunu belirtmiştir.

Araştırmanın verileri Antalya, Alanya ilçesindeki yerel halktan sadece $\mathrm{Y}$ ve $\mathrm{Z}$ kuşaklardan toplanmıştır. Aynı ölçekler ile farklı bölgelerde ve bütün kuşakları kapsayacak veriler toplanarak benzer bir çalışmanın gerçekleştirilmesi telekomünikasyon sektörü için önemli bilgiler sağlayabilir.

\section{Etik Beyan}

"Telekomünikasyon Sektöründe Müsteri Memnuniyeti ve Müsteri Değerinin Tavsiye Etme Niyetine Etkisi” başlıklı çalışmanın yazım sürecinde bilimsel, etik ve alıntı kurallarına uyulmuş; toplanan veriler üzerinde herhangi bir tahrifat yapılmamış ve bu çalışma herhangi başka bir akademik yayın ortamına değerlendirme için gönderilmemiştir. Bu araştırmanın verileri 01.01.2020 tarihinden önce (Kasım-Aralık 2019) toplandığ1 ve makalenin süreci 2020 yılında başladığından etik kurul kararı zorunluluğu taşımamaktadır.

\section{Kaynakça}

Aktepe, C. ve Baş, M. (2008). Marka bilgisi sürecinde marka farkındalığı ve algılanan kalite (beklenti) ilişkisi ve GSM sektörüne yönelik bir analiz. Gazi Üniversitesi İktisadi ve İdari Bilimler Fakïltesi Dergisi, 10(1), 81-96.

Alizadehfanaeloo, P. ve Özüdoğru, H. (2020). AVM imajının AVM ziyareti, müşteri memnuniyeti, müşteri sadakati ve ağızdan ağıza iletişim üzerindeki etkisi. $\dot{I}_{s}$ lettme Araştrrmalar Dergisi, 12(1), 848-865.

Alrwashdeh, M., Jahmani, A., Ibrahim, B. ve Aljuhmani, H. (2020). Data to model the effects of perceived telecommunication service quality and value on the degree of user satisfaction and e-WOM among telecommunications users in North Cyprus. Data in Brief, 28, Article No: 104981.

Altunel, M. (2013). Turistlerin beklenti ve deneyimleme kalitesinin tavsiye etme kararna etkisi: müze ziyaretçileri üzerine bir araștrma (Doktora Tezi). Dokuz Eylül UUniversitesi, Sosyal Bilimler Enstitüsü, İzmir.

Altunel, M. ve Erkut, B. (2015). Cultural tourism in Istanbul: The mediation effect of tourist experience and satisfaction on the relationship between involvement and recommendation intention. Journal of Destination Marketing \& Management, 4(4), 213-221.

Anderson, E. W., Fornell, C. ve Donald, R. L. (1994). Customer satisfaction, market share and profitability: Findings from Sweden. Journal of Marketing, 58(July), 53-66.

Andreassen, W. T. (2000). Antecedents to satisfaction with service recovery. European Journal of Marketing, 34(1), 156175.

Arasıl, Ö., Karaçuha, E., Özer, G. ve Aydın, S. (2004). Türk GSM sektöründe müşteri sadakati, memnuniyeti, güven ve değiştirme maliyeti arasındaki dinamik ilişkiler: Yapısal denklem modelleme tekniği. İktisat İsletme ve Finans, 19(219), 46-61.

Atmaca, E. ve Keskin, M. (2014). GSM operatörlerine yönelik müşteri memnuniyet araștırması. Çukurova Üniversitesi İktisadi ve İdari Bilimler Fakültesi Dergisi, 18(1), 45-63.

Aydeniz, N. ve Yüksel, D. (2007). Hizmet işletmelerinde pazar yönlü değer yaratma: finansal performansa etki boyutu. Elektronik Sosyal Bilimler Dergisi, 6(20), 95-111.

Babin, B. J., Lee, Y. K., Kim, E. J. ve Griffin, M. (2005). Modeling consumer satisfaction and word-of-mouth: Restaurant patronage in Korea. Journal of Services Marketing, 19(3), 133-139.

Belas, J. ve Gabcova, L. (2014). Reasons for satisfaction and dissatisfaction of bank customers: study from Slovakia and the Czech Republic. International Journal of Entrepreneurial Knowledge, 2(1), 4-13.

Brown, M. E., Trevino, L. K. ve Harrison, D. A. (2005). Ethical leadership: a social learning perspective for construct development and testing. Organizational Behavior and Human Decision Processes, 97, 117-134.

Butz, H. E. ve Goodstein, L. D. (1996). Measuring customer value: gaining the strategic advantage. Organizational Dynamics, 24(Winter), 63-77.

Danaher, P. T. ve Rust, R. T. (1996). Indirect financial benefits from service quality. Quality Management Journal, 3(2), 63-75.

Davras, Ö. ve Caber M. (2019). Analysis of hotel services by their symmetric and asymmetric effects on overall customer satisfaction: a comparison of market segments. International Journal of Hospitality Management, 81, 83-93. 
Dawes, P., Dowling, G. ve Patterson, P. (1991). Information sources used to select different types of management consultancy services. Asia Pacific Journal of Management, 8, 185-199.

Dubrovski, D. (2001). The role of customer satisfaction in achieving business excellence. Total Quality Management, 12(8), 920-925.

Dündar, S. ve Ecer, F. (2008). Öğrencilerin GSM operatörü tercihinin analitik hiyerarşi süreci yöntemiyle belirlenmesi. Yönetim ve Ekonomi: Celal Bayar Üniversitesi İktisadi ve İdari Bilimler Fakültesi Dergisi, 15(1), 195-205.

Eggert, A. ve Ulaga, W. (2002) Customer perceived value: a substitute for satisfaction in business markets?. Journal of Business \& Industrial Marketing, 17, 107-118.

Emir, O. ve Çelik, S. (2010). Beş yıldızlı termal otel işletmesi yöneticilerinin müşteri değeri algılarının belirlenmesi: Afyonkarahisar'da bir uygulama. Yönetim ve Ekonomi, 17(1), 69-82.

Fornell, C. (1992). A national customer satisfaction barometer the Swedish experience. Journal of Marketing, 56, 6-21.

Garbarino, E. ve Johnson, M. S. (1999). The different roles of satisfaction, trust, and commitment in customer relationships. Journal of Marketing, 63(2), 70-87.

Gerpott, T., Rams, W. ve Schindler, A. (2001). Customer retention, loyalty, and satisfaction in the German mobile cellular telecommunications market. Telecommunications Policy, 25, 249-269.

Goyette, I., Ricard, L., Bergeron, J. ve Marticotte, F. (2010). e-WOM scale: Word-of-Mouth measurement scale for eservices context. Canadian Journal of Administrative Sciences, 27(1), 5-23.

Gökdeniz, A. ve Aşık, N. (2008). Küresel rekabet ortamında turizm işletmelerinde soyut imaj oluşturma. Balıkesir Üniversitesi S.B.E. Dergisi, 11(20), 134-149.

Güler, E. G. (2009). Otel işletmelerinde değer yaratma ve müşteri değeri algılaması üzerine bir araştırma: Edirne’deki oteller örneği. Anatolia: Turiz̧ Araștırmalar Dergisi, 20(1), 61-76.

Hallowell, R. (1996). The relationships of customer satisfaction, customer loyalty, and profitability: an empirical study. International Journal of Service Industry Management, 7(4), 27-42.

Hartline, M. D. ve Jones, K. C. (1996). Employee performance cues in a hotel service environment: Influence on perceived service quality, value and word of mouth intentions. Journal of Business Research, 35, 207-215.

Hasim, M. A., Shamsudin, M. F., Ali, A. M. ve Shabi, S. (2018). The relationship between sales promotions and online impulse buying in Malaysia. Opcion, 34, 295-308.

Hassan, S., Ramayah, T. ve Maghsoudi, A. (2015). E-lifestyle, customer satisfaction, and loyalty among the generation Y mobile users. Asian Social Science, 11(4), 157-168.

Hennig-Thurau, T., Gwinner, K. P. ve Gremler D. D. (2002). Understanding relationship marketing outcomes: An integration of relational benefits and relationship quality. Journal of Service Research, 4(3), 230-247.

Hirata, E. (2019). Service characteristics and customer satisfaction in the container liner shipping industry. The Asian Journal of Shipping and Logistics, 35, 24-29.

Holbrook, M. B. (2005). Customer value and autoethnography: subjective personal introspection and the meanings of a photograph collection. Journal of Business Research, 58(1), 45-61.

Homburg, C. ve Bruhn, M. (1998). Customer loyalty management - An introduction to theoretical and practical problems. In M. Bruhn, \& C. Homburg (Eds.), Customer loyalty management manual (s. 3-35). Wiesbaden: Gabler.

Huang, J. ve Zhang, D. (2008). Customer value and brand loyalty: multi-dimensional empirical test. International Seminar on Future Information Technology and Management Engineering, Leicestershire, United Kingdom, s. 102-106.

Işık, S. (2011). GSM operatörlerinde bizmet kalitesi, müsteri memnuniyeti, algzlanan değer ve fiyatın ilişkilendirilmesi (Yüksek Lisans Tezi). Uşak Üniversitesi, Sosyal Bilimler Enstitüsü, Uşak.

Jani, D. ve Han, H. (2014). Personality, satisfaction, image, ambience, and loyalty: Testing their relationships in the hotel industry. International Journal of Hospitality Management, 37, 11-20.

Jin, Y. ve Su, M. (2009). Recommendation and repurchase intention thresholds: A joint heterogeneity response estimation. International Journal of Research in Marketing, 26, 245-255.

Kalaycı, Ş. (2014). SPSS uygulamal çok değişkenli istatistiksel teknikler. Ankara: Asil Yayın Dağıtım.

Karnowski, V. ve Jandura, O. (2014). When lifestyle becomes behavior: A closer look at the situational context of mobile communication. Telematics and Informatics, 31(2), 184-193.

Keiningham, T., Cooil, B., Andreassen, T. ve Aksoy, L. (2007). A longitudinal examination of net promoter and firm revenue growth. Journal of Marketing American Marketing Association, 71, 39-51.

Keller, K. L. (1993). Conceptualizing, measuring, and managing customer-based brand equity. Journal of Marketing, 57(1), 1-22.

Kim, J. H., Minjeon, K. ve Kandampully, J. (2007). The impact of buying environment characteristics of retail websites. The Service Industries Journal, 27(7), 865-880.

Kim, M., Park, M. ve Jeong, D. (2004). The effects of customer satisfaction and switching barrier on customer loyalty in Korean mobile telecommunication services. Telecommunications Policy, 28, 145-159.

Kocabaş, I. (2017). Çağnı merkezi müşteri temsilcisinin imajının müşteri memnuniyeti üzerindeki rolü. Gümüşhane Üniversitesi İletisim Fakültesi Elektronik Dergisi, 5(1), 147-118.

Levesque, T. ve McDougall, G. H. (1996). Determinants of customer satisfaction in retail banking. International Journal of Bank Marketing, 14(7), 12-20.

Lin, C. H., Sher, P. ve Shih, H. Y. (2005). Past progress and future directions in conceptualizing customer perceived value. International Journal of Service Industry Management, 16, 318-336. 
Mano, H. ve Oliver, R.L. (1993) Assessing the dimensionality and structure of the consumption experience: evaluation, feeling, and satisfaction. Journal of Consumer Research, 20, 451-466.

McDougall, G. H. ve Levesque, T. (2000). Customer satisfaction with services: putting perceived value into the equation. Journal of Services Marketing, 14(5), 392-410.

Mutlubaş, C. I. ve Soybalı, H. H. (2017). Müşteri memnuniyetini oluşturan faktörlerin müşteri sadakatine etkisinin lojistik regresyon analizi ile incelenmesi. Türk Turizm Araştırmalarn Dergisi, 1(3), 1-15.

Nusair, K., Parsa, H. G. ve Cobanoglu, C. (2011). Building a model of commitment for generation y: an empirical study on e-travel retailers. Tourism Management, 32(4), 833-843.

Olaru, D., Purchase, S. ve Peterson, N. (2008). Customer value in research organizations. Journal of Business \& Industrial Marketing, 23(8), 554-565.

Oliver, R. L. (1980). A cognitive model of the antecedents and consequences of satisfaction decisions. Journal of Marketing Research, 17(4), 460-469.

Oliver, R. L. (1993). A conceptual model of service quality and service satisfaction: compatible goals, different concepts. In Swartz, T. A., Bowen, D. E. \& Brown, S. W. (Eds.), Advances in service marketing and management (s. 65-85). Greenwich: JAI Press.

Otrar, M. ve Argın, F. S. (2015). Öğrencilerin sosyal medyaya ilişkin tutumlarını belirlemeye yönelik bir ölçek geliştirme çalışması. Journal of Research in Education and Teaching, 4(1), 391-403.

Parasuraman, A. (1997) Reflections on gaining competitive advantage through customer value. Journal of the Academy of Marketing Science, 25, 154-161.

Petrick, J. F. (2004) The roles of quality, value, and satisfaction in predicting cruise passengers' behavioral intentions. Journal of Travel Research, 42, 397-407.

Ranaweera, C. ve Prabhu, J. (2003). On the relative importance of customer satisfaction and trust as determinants of customer retention and positive word of mouth. Journal of Targeting, Measurement and Analysis for Marketing, 12, 82-90.

Razak, A. A. ve Shamsudin, M.F. (2019). The influence of atmospheric experience on Theme Park Tourist's satisfaction and loyalty in Malaysia. International Journal of Innovation, Creativity and Change, 6(9), 10-20.

Reichheld, F. (2003). The one number you need to grow. Harvard Business Review, 81, 46-54.

Saydan, R. (2008). Üniversite öğrencilerinin öğretim elemanlarından kalite beklentileri: yüzüncü y1l üniversitesi İIBF örneği. Gąi Üniversitesi İktisadi ve İdari Bilimler Fakültesi Dergisi, 10(1), 63-79.

Setiowati, R. ve Putri, A. (2012). The impact of perceived value on customer satisfaction, loyalty, recommendation and repurchase. An empirical study of SPA industry in Indonesia. International Conference on Trade, Tourism and Management, 21-22 December, 2012, Bangkok, Thailand.

Shamsudin, M. F. ve Razali, N. A. (2015). Factors influencing customer loyalty in private healthcare services. The International Journal of Social Sciences and Humanities Invention, 2, 1622-1625.

Shamsudin, M. F., Esa, S. A. ve Ali, A. M. (2019). Determinants of customer loyalty towards the hotel industry in Malaysia. International Journal of Innovation, Creativity and Change, 6(9), 21-29.

Silverman, G. (2001). The secrets of word-of-mouth marketing: How to trigger exponential sales through runaway word-of-mouth. New York: American Marketing Association.

Soderlund, M. ve Ohman, N.. (2003). Behavioral intentions in satisfaction research revisited. Journal of Consumer Satisfaction, Dissatisfaction and Complaining Behavior, 16, 53-66.

Soderlund, M. (2006). Measuring customer loyalty with multi-item scales: A case for caution. International Journal of Service Industry Management, 17(1), 76-98.

Şendur, F. (2009). Ilişkisel paz̧arlama çerçevesinde müsteri değeri yaratmanm önemi: Bankacıllk sektöründe bir araștırma (Yüksek Lisans Tezi). Balıkesir Üniversitesi, Sosyal Bilimler Enstitüsü, Balıkesir.

Tavşancıl, E. (2010). Tutumlarn ölcülmesi ve SPSS ile veri analizi. Ankara: Nobel Yayın Dağıtım.

Tavukçu, A. (2019). Iliş̧kisel pazarlama uygulamalarmm müsteri sadakati, müsteri memnuniyeti ve müsterilerin tavsiye etme eğilimi üzerine etkisi: Türk katılım bankacıliğ sektöründe bir araştırma (Yüksek Lisans Tezi). Bahçeşehir Üniversitesi, İstanbul.

Teo, R. ve Soutar, G. N. (2012). Word of mouth antecedents in an educational context: A Singaporean study. International Journal of Educational Management, 26(7), 678-695.

Tuncer, B. ve Kızgın Y. (2018), Tavsiye etme davranışının algılanan hizmet kalitesi değişkenleri ile ilişkisi: Atatürk havalimanı örneği. Business \& Management Studies: An International Journal, 6(3), 452-460.

Türker, G. ve Türker, A. (2013). GSM operatörleri sektöründe marka sadakatini etkileyen faktörlerin belirlenmesi; üniversite öğrencileri üzerine bir uygulama. Electronic Journal of Vocational Colleges, 3(1), 49-67.

Uzkurt, C. (2007). Tüketicilerin yenilikleri benimseme eğilimleri üzerinde kişisel değerlerin etkisi. Anadolu Üniversitesi Sosyal Bilimler Dergisi, 7(2), 241-260.

Uzkurt, C. ve Torlak, Ö. (2007). İşletmelerin müşteri değeri yaratma çabaları üzerinde öğrenme ve pazar odaklı kültürün etkileri. Hacettepe Üniversitesi İktisadi ve İdari Bilimler Fakültesi Dergisi, 25(1), 239-257.

Vavra, T. G. (1997). Improving your measurement of customer satisfaction: A guide to creating, conducting, analyzing, and reporting customer satisfaction measurement programs. Milwaukee: American Society for Quality Press.

Wang, Y., Lo, H., Chi, R. ve Yang, Y. (2004). An integrated framework for customer value and customer relationship management performance: A customer-based perspective from China. Managing Service Quality, 14, 169-182. 
Wilfert, A. (1999). Competition in the mobile communications market in Germany. In D. Fink \& A. Wilfert (Eds.), Handbook of telecommunications and business (s. 187-202). München: Vahlen.

Wong, S. W., Cheng, N. ve Yen, S. H. (2009). Grid reconfigurable optical-wireless architecture for large scale municipal mesh access network. IEEE Global Communications Conference, 30 November - 4 December 2009, Honolulu, Hawaii, (s. 1-6).

Woodruff, R. B. (1997) Customer value the next source of competitive advantage. Journal of the Academy of Marketing Science, 25, 139-153.

Yaşa, E. ve Bozyiğit, S. (2012). Y kuşağ1 tüketicilerinin cep telefonu ve GSM operatörleri tercihi: Mersin ilindeki üniversite öğrencilerinin tercihlerini belirlemeye yönelik pilot bir araştırma. Cag University Journal of Social Sciences, 9(1), 29-46.

Zeithaml, V. (1988). Consumer perceptions of price, quality and value: A means-end model and synthesis of evidence. Journal of Marketing, 52, 2-22.

Zeller, R. A. ve Carmines, E. G. (1978). Statistical analysis of social data. Chicago: Rand McNally College Publishing Company.

Zineldin, M. (2000). TRM Total Relationship Management. Lund: Studentlitterarur.

\section{EXTENDED ABSTRACT}

The customer is the most important part for businesses to continue their activities. Businesses not only want to retain their customers, but they also want to provide services to potential customers by increasing their market shares. From this perspective, the recommendation intention of existing customers is one of the most important advertising tool. Satisfied customers may tend to recommend business to their friends, families and surroundings and that can create customer value. The difference between the expectations of the customer before purchasing the product / service and the performance perceived after purchase or experience is expressed as satisfaction (Oliver, 1980, p. 460). Businesses that meet the expectations of the customers before the purchase or offer more are considered as reliable and quality services by customers. (Mutlubaş, \& Soyball, 2017). In other words, if the difference between the expectations of the customer before the purchase and the subsequent evaluations is large, customer satisfaction will be low (Saydan, 2008). If the business' products / services in the market do not provide customer satisfaction, the products / services of the business in the market may be seen as worthless by the customers (Kocabass, 2012). The concept of customer value is often confused with the concept of customer satisfaction. While the focus of customer satisfaction studies is to increase the level of customer satisfaction in the context of products / services, the focus of customer value studies is how customers choose the business and product / service among businesses offering similar products / services (Güler, 2009, p. 64). According to Aydeniz and Yüksel (2007, p. 108), word of mouth communication is an important factor in satisfying customers. Hartline and Jones (1996) stated that value positively affects their intention to recommend. The intention to recommend is the best way of predicting not only the behavior of the customer but also the purchasing behavior (Reichheld, 2003). In this context, the study aimed to examine effect of customer satisfaction and customer value on recommendation intention according to demographic variables in the telecommunications sector in Turkey. A questionnaire prepared with a 5point Likert was used to reach the objectives of the study. The survey consists of four sections. In the first part, there are items regarding the demographic characteristics of the participants (gender, year of birth, GSM operator used, year of using the operator, desire to switch to another operator). The survey includes customer satisfaction in the second part, customer value in the third part and intention to recommend in the fourth part. The customer satisfaction scale consists of 4 items and Croanbach Alpha (CA) value is 0.89 . The customer value scale consists of 3 items and the $\mathrm{CA}$ value is 0.85 . The recommendation scale consists of 5 items and the $\mathrm{CA}$ value is 0.91 . It can be suggested that the scales are reliable because the CA values are more than 0.60 (Kalayc1, 2014). The research population is the local community of Alanya district of Antalya city. According to TURKSTAT data, the population of Alanya district at 2018 is 327.503. For large samples, it is 384 of the sample group (n) which has the power to represent the main population with a sample error of 0.05 (Yazicioğlu, \& Erdoğan, 2004). This study is conducted on voluntarily basis. Therefore, the questionnaires were applied to the $\mathrm{Y}$ and $\mathrm{Z}$ generation voluntarily. The study was carried out with a total of 662 questionnaires. Data were collected during NovemberDecember 2019. Two different regression models were established to determine the effect of customer satisfaction and customer value on the intention to recommend in the context of $\mathrm{Y}$ and $\mathrm{Z}$ generations. According to the correlation results, there is a strong and positive relationship between customer satisfaction, customer value and intention to recommend in the context of generation $\mathrm{Y}$. In the context of generation $\mathrm{Y}$, customer satisfaction and customer value have an impact on the intention to recommend. The most important variable is customer satisfaction. According to the correlation results, there is a strong 
and positive relationship between customer satisfaction, customer value and intention to recommend in the context of $\mathrm{Z}$ generation. In the context of generation $\mathrm{Z}$, customer satisfaction and customer value have an impact on the intention to recommend. The most important variable is customer satisfaction. Since customer satisfaction has an effect on the intention of recommending more than customer value, GSM operators should give priority to customer satisfaction. Since there is a strong correlation between the variables, it should develop customer satisfaction and customer value strategies for increasing the recommendation of GSM operators, in other words, positive word of mouth communication. 